\title{
Chemical Composition of Seed Propagated Chestnut Genotypes from Northeastern Turkey
}

\author{
Mustafa AKBULUT ${ }^{1}$, Mehmet Ramazan BOZHUYUK², Sezai ERCISLI², \\ Azra SKENDER ${ }^{3}$, Karim SORKHEH ${ }^{4}$
}

\author{
${ }^{I}$ Recep Tayyip Erdoğan University, Faculty of Agriculture and Natural Sciences, 53900 Pazar, Rize, Turkey; makbuluttr@gmail.com \\ ${ }^{2}$ Ataturk University, Agricultural Faculty, Department of Horticulture, 25240 Erzurum, \\ Turkey;mrbozhuyuk@gmail.com;sercisli@gmail.com (*correspondingauthor) \\ ${ }^{3}$ University of Bihać, Biotechnical Faculty, Luke, Marjanovića bb, 77000 Bihać, Bosnia and Herzegovina; skenderharun@yahoo.com \\ ${ }^{4}$ Shahid Chamran University of Ahvaz, Faculty of Agriculture, Department of Agronomy and Plant Breeding, Iran; karimsorkheh@gmail.com
}

\begin{abstract}
Turkey ranked third place in the world for chestnut production after China and Bolivia and the country has unique chestnut populations including valuable and diverse seed propagated chestnut genotypes. In this study, chestnuts (Castanea sativa) were collected during the 2016 harvest season from Northeastern part of Turkey from promising 12 different seedling origin genotypes. Tree growth habit, nut weight, kernel ratio, kernel color, moisture, crude protein, crude fat, dietary fiber, total polyphenols, antioxidant activity and fatty acid content of fruits belongs to 12 genotypes were determined. The results showed that, the majority of genotypes had semi upright tree growth habit. The nut weight and kernel ratio were between 5.05 $\mathrm{g}(\mathrm{K}-10)$ and $10.10 \mathrm{~g}(\mathrm{~K}-5)$ and $71.10 \%(\mathrm{~K}-1)$ and $82.44 \%$ (K-3) among genotypes. The total crude fat content ranged from $0.87 \%(\mathrm{~K}-7)$ to $2.61 \%(\mathrm{~K}-1)$ while the crude protein ranged from $4.80 \%$ (K-7) to $7.65 \%(\mathrm{~K}-1)$. The dietary fiber content made up no more than $3.61 \%$ of the remaining portion of the kernel. It was found that total polyphenols was between 1.66 and 2.70 g GAE $/ \mathrm{kg}$ and antioxidant activity was between 5.80 and $9.07 \mu \mathrm{mol}$ Trolox equivalent $/ \mathrm{g}$ dry weight basis. Oleic and linoleic acid were the major fatty acids in all chestnut fruits and followed by palmitic and linolenic acid. The results showed that there was enough variations among seed propagated chestnut genotypes for most of the searched parameters and this highlights the importance of conserving the genotypes, as their high levels of heterogeneity allow them to respond to abiotic and biotic stresses and adapt to low-input farming systems.
\end{abstract}

Keywords: bioactive content, Castanea sativa, diversity, fatty acids, pomology

\section{Introduction}

Chestnut (Castanea sativa) is the oldest cultivated fruit in the world. The chestnut fruits have a high nutritional value and high-quality wood. In addition, chestnuts have significant economical value and medicinal importance for human health as sources of antioxidants, and as sources of other useful bioactive substances (Vasconcelos et al., 2010). Chestnut fruits are highly regarded and widely consumed throughout Europe, America and Asia. Various commercial forms are available, e.g. fresh and industrially processed. People consume it in large quantities; therefore, it has a very important role in public nutritional habits. Chestnut has a high calorie level, rich nutrient composition. Chestnuts contain high amount of carbohydrates, protein and dietary fiber. In addition, chestnuts differ from the other nuts for their low fat and salt content, which make them ideally suited for human nutrition and health (Mujic et al., 2010).

Chestnut is geographically distributed in three major areas: Europe with Castanea sativa Mill., Asia with Castanea creanata Sieb. and Zucc. (Japan) and Castanea mollissima Bl. (China and Korea), and North America with Castanea dentata Borkh. All Castanea species and their hybrids are edible and some are used in commercial nut production around the world (Bounous, 2005; Lang et al., 2006).

Major chestnut-producing countries in the world are China (1,685.000 tons), Bolivia (78,000 tons) Turkey $(64,000$ tons), South Korea (56,000 tons), and Italy $(52,000$ tons) (FAO, 2014). Turkey has a remarkable chestnut population of seed propagated chestnut genotypes when compared to other parts of the world (Erturk et al., 2006; Ertan, 2007; Serdar et al., 2009; Yildiz et al., 2009; Ormeci et al., 2016). 
426

Chestnut growing areas in Turkey spread from East of the Black Sea Region, through Marmara and Aegean Regions and reaches to in the Mediterranean Region in Anatolia (Ertan, 2007). In Turkey, chestnut production is mainly based on local heterogeneous genotypes, which represent examples of farmer selection carried out on-farm, and are named based on the geographical area of cultivation, without genetic or origin identification. Thus chestnut populations show considerable variations aspect of nut quality, tree characteristics, productivity, health status, and climatic adaptability. These genetic resources provide a good opportunity for genetic improvement. It seems that there were a lot of chestnut genotypes that free of chestnut blight (Cryphonectria parasitica) and ink disease (Phytopthora cambivora) damage in Turkey's forests (Ormeci et al., 2016).

The most important chestnut varieties in Turkey are 'Akkozak', 'Alimolla', 'Demirci', 'Dursun', 'Firdola', 'Haciibis,', 'Hacıömer', 'Halilibrahim', 'Inegölkestanesi', 'Tzmitli', 'Karamehmet', 'Korucu', 'Osmanoglu', 'Öküzgözü', 'Sarısșlama', 'Sarıkestane', and 'Tepeköysarısı' and all of them are selected among seed propagated chestnut populations (Mert and Erturk, 2017).

Recently, an increasing concern on chestnut and chestnut cultivation has been showing again in Turkey. The nuts are consumed directly in roasted or boiled form or evaluated as value added products such as chestnut desserts and candied chestnut (Mert and Erturk, 2017).

Previously, various composition and health studies clearly indicated that chestnut fruits, and potentially other extracts from chestnut trees, have considerable potential as functional foods or as food ingredients, e.g. chestnut polyphenolic extracts as a natural source of antioxidants and other beneficial compounds (Attanasio et al., 2004; Bernardez et al., 2004; De La Montana Miguelez et al., 2004; Pereira-Lorenzo et al., 2006). It has been previously shown that many ellagitannins, including castalagin and vescalagin, have potent antitumor, antioxidant, antimicrobial and antimalarial properties (Cerda et al., 2004; Seeram et al., 2005; Reddy et al., 2007).

In our study, a compositional comparison between different seed propagated chestnut genotypes was undertaken aiming at exploiting the nutrient profiles of natural growing chestnut fruits and promoting the further development of the rich chestnut resources. The present work was to investigate the twelve chestnut genotypes from Northeastern Turkey in terms of pomological (tree growth habit, nut weight, kernel ratio, kernel color) and proximate nutritive compounds (including moisture, crude protein, crude fat, crude fat, dietary fiber, total carbohydrates, total polyphenols, antioxidant activity and fatty acids).

\section{Materials and Methods}

\section{Plantmaterial}

This research was conducted at Rize province of Turkey in 2016. Among population, a total 12 seed propagated promising chestnut genotypes were marked in terms of better yield, nut size, earliness and resistance to chestnut blight and ink disease characteristics. The nut samples were collected from 12 promising genotypes. The $\mathrm{K}$ letter (K-1 to $\mathrm{K}-12)$ was assigned to the 12 genotypes.

\section{Pomologicaltraits}

Pomological characteristics and chemical content were conducted with four replications on a total 40 nuts per genotype. Nut weight was measured by using a digital balance with a sensitivity of $0.001 \mathrm{~g}$. Kernel ratio (\%) was counted considering nut and kernel weight (Ertan et al. 2007).

\section{Proximate analysis}

Kernel parts of nuts samples were used to assess moisture, crude protein, crude fat, dietary fiber, total carbohydrates, total polyphenols, and antioxidant activity. The moisture content of the chestnuts was determined by the gravimetric method using a drying oven at $105 \pm 2{ }^{\circ} \mathrm{C}$. The total nitrogen was analysed using the Kjeldahl method, and crude protein content was calculated using a nitrogen conversion factor of 5.30, which is specific for chestnut fruits (AOAC, 2000). Total fat was determined after extraction with ether for $16 \mathrm{~h}$ in a Soxhlet device (AOAC, 2000). The dinitrophenol method was utilized in the analysis of total carbohydrates (Ross, 1959) using spectrophotometer.

\section{Totalpolyphenol and antioxidant activity}

For total polyphenol analysis, the sample extraction was carried out combining $3 \mathrm{~g}$ of sample with $6 \mathrm{~mL}$ of $70 \%(\mathrm{v} / \mathrm{v})$ ethanol and homogenizing with an Ultra-Turrax homogenizer. The extract was shaken at $210 \mathrm{rpm}$ under refrigerated conditions for $15 \mathrm{~min}$ and then centrifuged for $15 \mathrm{~min}$ at 2346 $\mathrm{xg}\left(5^{\circ} \mathrm{C}\right)$. Before analysis, phenolic compounds were extracted by solid-phase extraction because substances such as reducing sugars, alcohol and tartaric acid, as well as antioxidant compounds (ascorbic acid) could interfere in the determination of polyphenols with the Folin-Ciocalteu reagent (Naczk and Shahidi, 2004). Commercially available octadecyl C18 cartridges $(1 \mathrm{~g}, 6 \mathrm{~mL})$ were used for the extraction of the phenolic fraction according to the following protocol: $2 \mathrm{~mL}$ of sample was loaded onto the column previously conditioned with $5 \mathrm{~mL}$ of methanol and $10 \mathrm{~mL}$ of water. The column was eluted with $4 \mathrm{~mL}$ of $0.02 \mathrm{~N}$ sulphuric acid to eliminate all the water-soluble compounds. The compounds retained by the column were recovered by eluting with $4 \mathrm{~mL}$ of $60 \%(\mathrm{v} / \mathrm{v})$ methanol solution. Total polyphenol content was determined by the colorimetric reaction with the Folin-Ciocalteu reagent (Singleton and Rossi, 1965). Gallic acid was used as an external standard for the calibration curve and results were expressed as g of gallic acid equivalents (GAE) per $\mathrm{kg}$ of dry weight.

For antioxidant activity determination, the sample extraction was carried out combining $3 \mathrm{~g}$ of sample with $6 \mathrm{~mL}$ of $70 \%(\mathrm{v} / \mathrm{v})$ ethanol and homogenizing with an Ultra Turrax homogenizer. The extract was shaken at $180 \mathrm{rpm}$ under refrigerated condition for $15 \mathrm{~min}$ then centrifuged for $15 \mathrm{~min}$ at $2346 \times \mathrm{g}\left(5^{\circ} \mathrm{C}\right)$. The radical-scavenging activity was determined soon after extraction by the ABTS ${ }^{+}$radical cation decolourization assay, as described by Re et al. (1999). The bleaching rate of $\mathrm{ABTS}^{+}$in the presence of the sample was monitored at $734 \mathrm{~nm}$ by a spectrometer. A volume of $2.97 \mathrm{~mL}$ of $\mathrm{ABTS}^{+}$solution was used. The reaction was started by the addition of $30 \mathrm{~mL}$ of the ethanolic extract diluted up to $1: 10$. $\mathrm{ABTS}^{+}$bleaching was monitored at $25^{\circ} \mathrm{C}$ for at least $30 \mathrm{~min}$ and the percentage of decolouration after $7 \mathrm{~min}$ was used as the measure of antioxidant activity. In this dilution range, the $\mathrm{ABTS}^{+}$bleaching was proportional to the concentration of the 
sample added to the medium, and a linear model fit to the dose-response curve. Antioxidant activity was calculated by the ratio of the regression coefficient of the dose-response curve of the sample and the regression coefficient of the dose-response curve of Trolox (hydrophilic homologue of a-tocopherol), and was expressed as $\mu \mathrm{mol}$ of Trolox equivalents per $\mathrm{g}$ of sample (dry weight basis).

\section{Fatty acid analysis}

Fatty Acids were prepared by hydrolysis with a $2 \mathrm{M}$ methanolic potassium hydroxide solution, and extraction with n-heptane, in accordance with ISO 5509 method (ISO, 2000) and following a procedure described in a previous work (Barreira et al., 2009). The fatty acids profile was evaluated with a Chrompack CP 9001 chromatograph equipped with a splitsplitless injector, a flame ionization detector (FID), and a Chrompack CP-9050 auto-sampler. Separation was achieved on a $50 \mathrm{~m} \times 0.25 \mathrm{~mm}$ i.d. fused silica capillary column coated with a $0.19 \mathrm{~lm}$ film of CP-Sil 88 (Chrompack). Helium was used as carrier gas at an internal pressure of $120 \mathrm{kPa}$. The results are expressed in relative percent-age of each fatty acid, calculated by internal normalization of the chromatographic peak area, and assuming that the detector response was the same for all compounds.

\section{Statistical analysis}

The experiment was a completely randomized design with four replications. The replications were done from the measuring solutions Data were subjected to analysis of variance (ANOVA) and means were separated by LSD test at $\mathrm{p}<0.05$ significant levels.

\section{Results and Discussion}

\section{Pomological traits}

In present study, tree growth habits and kernel color of 12 genotypes are mostly semi upright and light cream (Table 1). Serdar et al. (2011) reported that the chestnut cultivars 'Serdar' and 'Marigoule' have semi upright tree growth habit and light cream and cream kernel color.

The nut weight varied from $5.03 \mathrm{~g}(\mathrm{~K}-10)$ to $10.10 \mathrm{~g}(\mathrm{~K}-5)$ (Table 1). Serdar (2002) selected 13 new chestnut genotypes in

Table 1. Some pomological characteristics of genotypes

\begin{tabular}{ccccc}
\hline $\begin{array}{c}\text { Genotyp/ } \\
\text { Cultivars }\end{array}$ & $\begin{array}{c}\text { Tree growth } \\
\text { habits }\end{array}$ & $\begin{array}{c}\text { Average } \\
\text { nut } \\
\text { weight }(\mathrm{g})\end{array}$ & $\begin{array}{c}\text { Average } \\
\text { kernel } \\
\text { ratio }(\%)\end{array}$ & $\begin{array}{c}\text { Kernel } \\
\text { color }\end{array}$ \\
\hline K-1 & Semi upright & 6.27 & 71.10 & Cream \\
K-2 & Spreading & 5.83 & 74.43 & Light cream \\
K-3 & Semi upright & 9.32 & 82.44 & Light cream \\
K-4 & Semi upright & 7.16 & 76.38 & Cream \\
K-5 & Spreading & 10.10 & 80.76 & Cream \\
K-6 & Semi upright & 8.74 & 75.40 & Dark cream \\
K-7 & Semi upright & 7.49 & 77.62 & Cream \\
K-8 & Spreading & 5.56 & 81.59 & Light cream \\
K-9 & Semi upright & 9.38 & 80.37 & Light cream \\
K-10 & Semi upright & 5.03 & 75.29 & Light cream \\
K-11 & Semi upright & 6.27 & 78.44 & Cream \\
K-12 & Semi upright & 7.81 & 80.15 & Light cream \\
LSD 0.05 & & 2.18 & 4.57 & \\
\hline
\end{tabular}

Camili vicinity of Northeastern part of Turkey and average nut weight varied between 4.79 to $7.45 \mathrm{~g}$ respectively. Nut weight of 12 chestnut genotypes were comparable to previously selected genotypes of chestnuts in China (Ding, 1993), in India (Pandit et al. 2011), in Slovenia (Solar et al. 2005) and in Bosnia \& Herzegovina (Mujic et al., 2010).

Kernel ratio of the 12 chestnut genotypes varied from $71.10 \%(\mathrm{~K}-1)$ to $82.44 \%$ (K-3), respectively (Table 1$)$. In our study, kernel ratio of 12 genotypes was similar to other studies (Serdar, 2002; Ertan et al. 2007). Mujic et al. (2010) reported the percentage of kernel was ranged from 78.5 to $87.3 \%$ in non-grafted chestnuts in Bosnia \& Herzegovina. Ertan (2007) reported percentage of kernel among European chestnuts from ten different areas in Turkey between 75.9 to $86.1 \%$.

\section{Proximate composition}

The moisture, total crude protein, crude fat, total carbohydrates and dietary fiber content are shown in Table 2. Moisture, protein, fat, carbohydrate and fiber content varied from $45.11 \%(\mathrm{~K}-1)$ to $54.27 \%(\mathrm{~K}-7)$; $4.80 \%$ (K-7) to $7.65 \%$ (K-1); $0.87 \%(\mathrm{~K}-7)$ to $2.61 \%(\mathrm{~K}-1) ; 52.33 \%(\mathrm{~K}-7)$ to $62.10 \%$ (K-1) and $2.06 \%(\mathrm{~K}-4)$ to $3.61 \%$ (K-1), respectively (Table 2). Mert and Erturk (2017) reported kernel composition of 19 local and foreign chestnut cultivars were $5.58-7.35 \mathrm{~g} / 100 \mathrm{~g}$ protein; $58.18-66.21 \mathrm{~g} / 100 \mathrm{~g}$ total carbohydrates (on the dry matter basis). Bernardez et al. (2004) reported moisture contents of chestnuts in Spain between 48.37-59.35\%. PereiraLorenzo et al., (2006) and De La Montana Miguelez et al. (2004) determined the same parameter as $54 \%$ and $49 \%$, respectively. The total protein content was reported between 4.50 and $10.87 \mathrm{~g} / 100 \mathrm{~g}$ by different researchers in C. sativa Mill. (De La Montana Miguelez et al., 2004; Ertan and Kilınç, 2005; Ertürk et al., 2006; Pereira-Lorenzo et al., 2006; Mert and Erturk (2017). Our results are similar to the previous results. Mert and Erturk (2017) reported total carbohydrate quantities of chestnuts fruits between 58.18 and $66.21 \%$ depending on cultivar (Table 2). Erturk et al. (2006) reported that this component in Castanea sativa Mill. cultivars between 75.32 and $86.31 \%$. Results of this research were comparable with above results.

Table 2. Proximate composition of chestnut fruits of 12 genotypes (dry weight basis per $100 \mathrm{~g}$ )

\begin{tabular}{cccccc}
\hline $\begin{array}{c}\text { Genotypes/ } \\
\text { Cultivars }\end{array}$ & $\begin{array}{c}\text { Moisture } \\
(\%)\end{array}$ & $\begin{array}{c}\text { Crude } \\
\text { Protein } \\
(\%)\end{array}$ & $\begin{array}{c}\text { Crude } \\
\text { Fat } \\
(\%)\end{array}$ & $\begin{array}{c}\text { Carbo- } \\
\text { hydrate } \\
(\%)\end{array}$ & $\begin{array}{c}\text { Dietary } \\
\text { Fiber } \\
(\%)\end{array}$ \\
\hline K-1 & 45.11 & 7.65 & 2.40 & 62.10 & 3.61 \\
K-2 & 47.98 & 6.98 & 1.97 & 58.64 & 2.14 \\
K-3 & 46.16 & 7.45 & 2.49 & 60.18 & 2.73 \\
K-4 & 47.43 & 6.94 & 1.44 & 57.52 & 2.06 \\
K-5 & 50.30 & 6.05 & 1.65 & 55.44 & 2.55 \\
K-6 & 49.15 & 6.37 & 1.16 & 59.51 & 2.80 \\
K-7 & 54.27 & 4.80 & 0.93 & 52.23 & 2.27 \\
K-8 & 48.35 & 5.67 & 1.12 & 53.17 & 2.44 \\
K-9 & 47.66 & 7.10 & 1.35 & 57.41 & 3.15 \\
K-10 & 50.10 & 5.98 & 1.51 & 56.49 & 2.38 \\
K-11 & 52.11 & 5.57 & 0.97 & 54.49 & 3.03 \\
\hline K-12 & 49.55 & 6.59 & 1.96 & 60.87 & 2.95 \\
LSD 0.05 & 4.22 & 1.98 & 0.36 & 3.89 & 0.34 \\
\hline
\end{tabular}


Comparing to the other nuts such as walnut, hazelnut etc., chestnuts differ from other nuts and have lower fat (2.0-5.0\%) content. The crude indicate significant classes among the cultivars ( $p<0.05)$. Mert and Erturk (2017) reported the crude fat amount chestnut cultivars ranged from 0.87 to $2.61 \%$. Our results are in accordance with those obtained by Erturk et al. (2006) for C. sativa and hybrid cultivars, for Italian cultivars (Sacchetti and Pinnavaia, 2005) and for Spanish cultivars (De La Montana Miguelez et al., 2004 and PereiraLorenzo et al., 2006)

Previous studies indicated cultivar/genotype differences on chemical content of fruit species, including stone fruits, nuts, berries and subtropical fruits (Celik et al., 2007; Ercisli, 2009; Ercisli et al., 2010; Erturk et al., 2010; Saridas et al., 2016; Yazici and Sahin, 2016; Zorenc et al., 2016).

\section{Totalpolyphenols and antioxidant activity}

Total polyphenols was between 1.66 and $2.70 \mathrm{~g} \mathrm{GAE} / \mathrm{kg}$ on dry weight basis and antioxidant activity was between 5.80 and $9.07 \mu \mathrm{mol}$ Trolox equivalent/g dry weight (Table 3). There were statistical differences among genotypes on these parameters $(p<0.05)$. These results make it possible to classify chestnut among fruits with low polyphenol content (Vinson $e t$ al., 2001). Our polyphenol data were slightly higher than those results (1.27-2.35 g/kg d.w.) reported by Vekiari et al. (2006), which found the highest values in Spanish chestnuts followed by Greek nuts. In this study, the antioxidant activity of chestnuts was measured with a method extensively used in literature, expressed in terms of $\mu \mathrm{mol}$ of Trolox equivalents on $\mathrm{g}$ dry fresh and the values were compared with those obtained on other fruits and vegetables by the same method of analysis. The antioxidant activity of the 12 chestnut genotypes represents a median value between the TEAC values of other fruits as reported by Pellegrini $e t a l$. (2003).

\section{Fatty acids}

Table 4 shows the fatty acids profiles data reported as mean value of each genotype. The results show that chestnuts genotypes were a significant source of variation for the majority of fatty acids. Oleic acid is the most abundant, varying from $34.3 \% \quad(\mathrm{~K}-6)$ to $41.7 \% \quad(\mathrm{~K}-2)$ among genotypes. Polyunsaturated fatty acid (PUFA) seemed to be favored for most of the genotypes and linoleic acid was evidently the major PUFA, with contents ranging from $33.2 \%(\mathrm{~K}-4)$ and $39.4 \%$ (K-1) (Table 4). The high amount of this PUFA represents a well-known advantage, since it is classified as an essential fatty acids (Emken et al., 1994).

Results demonstrated that chestnut lipidic fraction is mainly constituted by three fatty acids: linoleic, oleic and palmitic acids accounting for more than $90 \%$ of the total fatty acid content, a value slightly higher or similar when compared with the results obtained by other research groups (Borges et al., 2007; Barreira et al., 2012), most likely due to the different origin of chestnut samples. Currently, consumers are showing an increased interest in chestnuts because of their nutritional qualities and potentially beneficial health effects, including the well-known advantages of omega-3 and omega-6 polyunsaturated fatty acids (PUFA), whose intake is insufficient in Western diets (Simopoulos, 1991). Particularly linoleic acid plays an important role in preventing cardiovascular diseases in adults, promoting the brain and retina development in infants (Simopoulos, 1991; Senter et al., 1994; Künsch et al., 1999) or preventing DNA damage (Kok et al., 2003).

Table 3. Means of the polyphenols concentration and antioxidant activity of chestnuts (dry weight basis)

\begin{tabular}{ccc}
\hline $\begin{array}{c}\text { Genotypes/ } \\
\text { Cultivars }\end{array}$ & $\begin{array}{c}\text { Total polyphenols } \\
(\mathrm{g} \text { GAE/kg })\end{array}$ & $\begin{array}{c}\text { Antioxidant activity } \\
(\mu \text { mol_Trolox equal/g) }\end{array}$ \\
\hline K-1 & 2.56 & 8.85 \\
K-2 & 1.94 & 7.11 \\
K-3 & 1.82 & 6.94 \\
K-4 & 2.42 & 8.34 \\
K-5 & 2.10 & 7.68 \\
\hline K-6 & 2.70 & 9.07 \\
K-7 & 2.20 & 8.02 \\
K-8 & 1.78 & 5.80 \\
\hline K-9 & 1.82 & 6.38 \\
K-10 & 1.88 & 6.11 \\
K-11 & 2.14 & 7.96 \\
K-12 & 1.66 & 5.97 \\
\hline LSD 0.05 & 0.14 & 2.12 \\
\hline NS: not significant. & & \\
\hline
\end{tabular}

Table 4. Means of the fatty acids of genotypes (dry weight basis per $g$ fruit)

\begin{tabular}{ccccc}
\hline $\begin{array}{c}\text { Genotypes/ } \\
\text { Cultivars }\end{array}$ & $\begin{array}{c}16: 0 \\
(\%)\end{array}$ & $\begin{array}{c}18: 1 \\
(\%)\end{array}$ & $\begin{array}{c}18: 2 \\
(\%)\end{array}$ & $\begin{array}{c}18: 3 \\
(\%)\end{array}$ \\
\hline K-1 & 13.2 & 38.7 & 39.4 & 3.8 \\
\hline K-2 & 16.3 & 41.7 & 35.1 & 3.9 \\
K-3 & 15.5 & 40.3 & 35.7 & 3.9 \\
\hline K-4 & 12.1 & 36.2 & 33.2 & 3.6 \\
K-5 & 17.2 & 40.9 & 38.6 & 4.0 \\
\hline K-6 & 15.1 & 34.3 & 37.8 & 3.8 \\
\hline K-7 & 18.1 & 36.5 & 35.3 & 4.7 \\
\hline K-8 & 17.8 & 35.9 & 38.6 & 3.7 \\
K-9 & 14.7 & 34.9 & 33.9 & 4.3 \\
\hline K-10 & 13.8 & 37.6 & 36.8 & 4.1 \\
\hline K-11 & 15.9 & 37.0 & 37.5 & 4.3 \\
\hline K-12 & 17.0 & 37.9 & 35.0 & 4.0 \\
LSD $_{0.05}$ & 1.7 & 2.8 & 2.6 & 0.5 \\
\hline
\end{tabular}

\section{Conclusions}

The present study highlighted the pomological values and bioactive compositions varied among wild grown chestnuts. This may have important for future breeding activities to select better genotypes to use in cross breeding studies. Present study also showed that chestnut fruits are one of the most promising natural antioxidant sources. Therefore, utilizing wild grown chestnuts as sources of phytochemicals could offer enormous opportunities for the functional food industry. These efforts highlight the need for the assessment of this traditional germplasm under different profiles, fundamental for its protection and conservation. The value of plant genetic resources lies in producing new cultivars, and in responding to new challenges based on systems of sustainable production and improved nutritional quality. 


\section{References}

AOAC (2000). Official methods of analysis (17th Ed.). Washington, DC: Association of Official Analytical Chemists.

Attanasio G, Cinquanta L, Albanese D and Matteo M (2004). Effects of drying temperatures on physico-chemical properties of dried and rehydrated chestnuts (Castaneasativa). Food Chemistry 88:583-590.

Barreira JCM, Casal S, Ferreira ICFR, Oliveira MBPP, Pereira JA (2009). Nutritional, fatty acid and triacylgycerol profiles of Castanea sativa Mill. cultivars: a compositional and chemometric approach. Journal of Agricultural and Food Chemistry 57:2836-2842.

Barreira JCM, Casal S, Ferreira ICFR, Peres AM, Pereira JA, Oliveira MBPP (2012. Chemical characterization of chestnut cultivars from three consecutive years: Chemometrics and contribution for authentication. Food and Chemical Toxicology 50:2311-2317.

Bernardez MM, Miguelez JM and Queijeiro JG (2004). HPLC determination of sugars in varieties of chestnut fruits from Galicia (Spain). Journal of Food Composition and Analysis 17:63-67.

Borges OP, Carvalho JS, Correia PR, Silva AP (2007). Lipid and fatty acid profiles of Castanea sativa Mill. Chestnuts of 17 native Portuguese cultivars. Journal of Food Composition and Analysis 20:80-89.

Bounous G (2005). The chestnut: a multipurpose resource for the new millennium. Acta Horticulturae 693:33-40.

Celik A, Ercisli S, Turgut N (2007). Some physical, pomological and nutritional properties of kiwifruit cr. Hayward. International Journal of Food Sciences and Nutrition. 58(6):411-418.

Cerda B, Espin JC, Parra S, Martinez P and Tomas-Barberan FA (2004). The potent in vitro antioxidant ellagitannins from pomegranate juice are metabolised into bioavailable but poor antioxidant hydroxy- $6 \mathrm{H}$ dibenzopyran-6- one derivatives by the colonic microflora of healthy humans. European Journal of Nutrition 43:205-220.

De La Montana Miguelez J, Miguez Bernardez M, Garcia Queijeiro JM (2004). Composition of varieties of chestnuts from Galicia (Spain). Food Chemistry 84(3): 401-404.

Ding XY. (1993). Chestnut cultivars of Hennan province and their cultivation. Journal Fruit Science 10(3):184-185.

Emken EA, Adlof RO, Gulley RM (1994). Dietary linoleic acid influences desaturation and acylation of deuterium-labeled linoleic and linolenic acids in young adult males. Biochimica at Biophysica Acta 1213: 277288.

Ercisli (2009). Apricot culture in Turkey. Scientific Research and Essays 4: 715-719.

Ercisli S, Tosun M, Duralija B, Voca S, Sengul M, Turan M (2010). Phytochemical content of some black (Morus nigra L.) and purple (Morus rubra L.) mulberry genotypes. Food Technology and Biotechnology 48(1): 102-106.

Ertan E (2007). Variability in leaf and fruit morphology and in fruit composition of chestnuts (Castanea sativa Mill.) in the Nazilli Region of Turkey. Genet Resources and Crop Evolution 54(4):691-699.

Ertan E, Seferoglu G, Dalkilic GG, Tekintas FE, Seferoglu S, Babaeren F, Onal M,DalkilicZ (2007). Selection of chestnuts (Castanea sativa Mill.) grown in Nazilli district, Turkey. Turkish Journal of Agriculture and Forestry31:115-123.
Erturk Y,ErcisliS, Haznedar A, Cakmakci R (2010). Effects of plant growth promoting rhizobacteria (PGPR) on rooting and root growth of kiwifruit (Actinidia deliciosa) stem cuttings. Biological Research 43: 9198.

Erturk U, Mert C, Soylu A (2006). Chemical composition of fruits of some important chestnut cultivars. Brazilian Archives of Biology and Technology 49(2):183-188.

FAO (2014). Food and Agricultural Organization. Crop statistical database. Accessed 5 May 2016.

International Standardization Organization 5509 (2000). Animal and vegetable fats and oils-Preparation of methyl esters of fatty acids.

Kok TMCM,Zwingman I, Moonen EJ, Schilderman PAEL, Rhijnsburger E, Haenen GRMM, Kleinjans JCS (2003). Analysis of oxidative DNA damage after human dietary supplementation with linoleic acid. Food and Chemical Toxicology 41:351-358.

Künsch U, Scharer H, Conedera M, Sassella A, Jermini M, Jelmini G (1999). Quality assessment of chestnut fruits. Acta Horticulturae 494:119-127.

Lang P, Dane F, Kubisiak TL (2006). Phylogeny of Castanea (Fagaceae) based on chloroplast trnT-L-F sequence data. Tree Genetics \& Genomes 2:132-139.

Mert C, Erturk U (2017). Chemical compositions and sugar profiles of consumed chestnut cultivars in the Marmara Region, Turkey. Notulae Botanicae Horti Agrobotanici Cluj-Napoca 45(1):203-207.

Mujic I, Agayn V,ZivkovicJ, VelicD, Alibabic V, Rekic A (2010). Chestnuts a comfort'Health Food'. Acta Horticulturae 866: 659-665.

Naczk M, Shahidi F (2004). Extraction and analysis of phenolics in food. Journal of Chromatography A 1054:95-111.

Ormeci Y, Akca Y, Ercisli S (2016). Selection of promising chestnuts (Castanea sativa) among wild growing trees from Southern Mediterranean region of Turkey. Journal of Forestry Research 27 2): 349-355.

Pandit AH, Mir MA, Kour A, Bhat KM (2011). Variability and selection of chestnut (Castanea sativa Mill.) in Srinagar District of the Kashmir Valley. Pakistan Journal of Agricultural Science 50(2):205-209.

Pellegrini N, Serafini M, Colombi C, Del Rio D, Salvatore S, Bianchi M, Brighenti $F$ (2003). Total antioxidant capacity of plant foods, beverages and oils consumed in Italy assessed by three different in vitro assay. Journal of Nutrition 133:2812-2819.

Pereira-Lorenzo S, Ramos-Cabrer AM, Diaz-Hernandez MB, Ciordia-Ara M, Rios-Mesa D (2006). Chemical composition of chestnut cultivars from Spain. Scientia Horticulturae 107:306-314.

Re R, Pellegrini N, Proteggente A, Pannala A, Yang M, Rice Evans C (1999). Antioxidant activity applying an improved ABTS radical cation decolorization assay. Free Radical Biology \& Medicine 26:1231-1237.

ReddyMK, GuptaSK,JacobMR, Khan SI, Ferreira D (2007). Antioxidant, antimalarial and antimicrobial activities of tannin-rich fractions, ellagitannins and phenolic acids from Punica granatum L. Planta Medica 73:461-467.

Ross FA (1959). Dinitrophenol methods for reducing sugars. In: Talburt WF, Smith O (Eds.). Potato Processing. A VI Publishing Comp Connecticut $469-470$.

Sacchetti G, Pinnavaia GG (2005). Compositional characteristics of some 
430

chestnut biotypes of Emiliano-Romagnolo Apennine. Acta Horticulturae 693:241-245.

Saridas MA, Kafkas NE, Zarifikhosroshahi M, Bozhaydar O, Kargi SP (2016). Quality traits of green plums (Prunus cerasifera Ehrh.) at different maturity stages. Turkish Journal of Agriculture and Forestry 40:655-663.

Seeram NP, Adam LS, Henning SM, Niu Y, Zhang Y, Nair MG, Heber D (2005). In vitro antiproliferative, apoptotic and antioxidant activities of punicalagin, ellagic acid and a total pomegranate tannin extract are enhanced in combination with other polyphenols as found in pomegranate juice. The Journal of Nutritional Biochemistry 16:360367.

SenterSD, PayneJA, Miller G, Anagnosakis SL (1994). Comparison of total lipids, fatty acids sugars and non-volatile organic acids in nuts from four Castanea species. Journal of the Science of Food and Agriculture 65 (2): 223-227.

Serdar U (2002). Chestnut selection in Camili vicinity (Artvin-Borçka). Journal Faculty Agriculture OMU 17:57-30.

Serdar U, Demirsoy H, Demirsoy L (2009). Determination of superior chestnut genotypes in the central black sea region of Turkey. Acta Horticulturae 815:37-42.

Serdar U, Demirsoy H, Demirsoy L (2011). A morphological and phenological comparison of chestnut (Castanea) cultivars 'Serdar' and 'Marigoule'. Australian Journal of Crop Science 5(11): 1311-1317.

Simopoulos AP (1991). Omega-3 fatty acids in health and disease and in growth and development. The American Journal of Clinical Nutrition 54:438-463.
Singleton VL, Rossi J (1965). A colorimetry of total phenolics with phosphomolibdic acid-phosphotungstic acid reagent. American Journal of Enology and Viticulture 16:144158.

Solar A, Podjavorsek A, Stampar F (2005). Phenotypic and genotypic diversity of European chestnut (Castanea sativa Mill.) in Sloveniaopportunity for genetic improvement. Genet Resources and Crop Evolution 52:381-394.

Vasconcelos MCBM, Bennett RN, Rosa EAS, Ferreira-Cardoso JV (2010). Composition of European chestnut (Castanea sativa Mill.) and association with health effects: fresh and processed products. Journal of the Science of Food and Agriculture 90:1578-1589.

Vekiari SA, Panagou E, Mallidis C (2006). Compositional analysis of chestnuts in Mediterranean countries. Advances Horticultural Science 20:90-95.

Vinson JA, Su X, Zubik L, Bose P (2001). Phenol antioxidant quantity and quality in foods: fruits. Journal of Agricultural and Food Chemistry 49:5315-5321.

Yazici K, Sahin A (2016). Characterization of pomegranate (Punica granatum L.) hybrids and their potential use in further breeding. Turkish Journal of Agriculture and Forestry 40:813-824.

Zorenc Z, Veberic R, Stampar F, Koron D, Mikulic-Petkovsek M (2016). Changes in berry quality of northern highbush blueberry (Vaccinium corymbosum L.) during the harvest season. Turkish Journal of AgricultureandForestry 40, 855-864.

Yildiz MU, Ozcan MM, Calisir S, Demir F, Er F (2009). Physicochemical properties of wild chestnut (Castanea sativa Mill) fruit grown in Turkey. World Applied Sciences Journal 6(3):365-372. 